\title{
AN INTRODUCTION TO THE ANCIENT CONCEPTS OF DEMONS: A BRIEF NOTE ON THE ANCIENT EGYPTIAN BELIEFS
}

\section{Abstract}

The objective of this text is to offer an introduction to the conceptualization of evil within the religious beliefs and to bring closer to the Macedonian public the basic definitions regarding the concept of evil incarnate, through the beliefs in demons in Ancient Egypt. Therefore, some fundamental terminological distinctions are briefly mentioned, concerning the use of demon and daimon in ancient contexts, as well as the basic conceptual framework of the demonic, the hybrid, the monstrous. A basic comparison is made between the nature of demons in the Eastern civilizations and the daimons of the Greek intellectual culture, and some light is shed on the differences between the ancient and the Christian (and modern) understanding of evil incarnate, as well as on the monstrosity or the "existence between" of creatures with an uncertain ontological status and a potentially menacing nature.

Some attention is paid to these "creatures between", believed to move between the different realities (the earth and the underworld, the world of the living and of the dead, the profane and the sacred), which should not be determined as strictly, or purely, evil and harmful. The text examines the types of demons from the aspect of their nefariousness or usefulness, as well as from the aspect of their topography (wanderers vs. fixed ones); the ways in which the harmful (mobile) demons proliferate diseases and attack the souls and bodies of the human patients, as well as the importance of the magico-medial protection against such influences; and the ways in which the useful guardian-demons (fixed in certain places, on earth or the Netherworld), participate in preserving the safety of the chosen areas they protect. Some attention is given, thus, to the importance which both categories of demons have in understanding the functioning of the Netherworld.

The ancient beliefs in the demonic, besides it being seen as threatening, dangerous, and nefarious, include a certain ambivalence of the concepts: the harmful demons, disease-bringers, bringers of problems and troubles, sometimes act according to the orders by the gods, or serve to punish the sinful in the Netherworld. The useful demons have key ontological roles in keeping the balance between the worlds, by serving as keepers and guardians of the gates to the Netherworld, the entrances to the sacred places, the sacred realms, and the liminal spheres. Thus, an attempt is made with this text to underline the need for a broad approach in the understanding of the concept of the demonic.

Key words: demon, daimon, ancient Egypt, guardians, the Netherworld. 


\section{The basics of "demonic" terminology}

In the theories of religion, in anthropology and ethnology, different terms refer to the evil creatures, often aligned with the local religious culture in question. In this sense, an entity that would be simply labeled a "demon" in a broader meaning, within the local contexts is some sort of a frightening, violent, nefarious creature with its own name, nature, and characteristics. The term demon carries a complex meaning, with different connotations in varying contexts and spatio-temporal frameworks. For the ancient Greeks, for example, a daimon (the term being the root for our later demon) was a divine creature of any kind. The religious cultures of Mesopotamia and Ancient Egypt abound with textual and iconographic examples from which it becomes clear how important and diverse the belief in demons (or various demonic creatures) used to be.

The conceptualization of an incarnate, personified demonic evil, of demonic agents in the world, is very important for the Egyptian belief in the workings of the cosmos - from the very sustainability of being to the particular vicissitudes of individual existence. Or rather, the reverse could be true: it was precisely the belief in magic and the power of demonic actions that formed an essential thread between the individual human existence and the levels of nature, the cosmos, the realm of the gods. The notion of magic, heka, does not have a pejorative connotation in the language and ideology, otherwise typical of the Western European treatment of the concept. In the ancient Egyptian linguistic tradition, there is no term for the demonic (Kousoulis, 2011, IX-X). Words like demon and demonology (in their modern language variations), used in a contemporary context, find their roots in the Judeo-Christian cultural tradition, and are therefore often seen as unfavorable (evil) aspects of the religious or artistic conceptualization, and as linked to bad (religious) practices. It would be unfair and misplaced, however, to impose such an atmosphere of suspicion and disapproval on concepts that have previously existed for thousands of years. Another problem is the existence of the demonic creatures: the majority of them have no clear ontological status that would simply enable them to be included in a group of entities researched by "demonology" as a sub-discipline, nor have they got a clear and unchangeable status and a fixed position within the Egyptian belief system.

The basic meanings of the Greek verb $\delta \alpha \mu$ ov $\alpha \omega$ are to be under the power of a demon, to be possessed, to suffer by a demonic visitation, and refer to the influence which (most commonly) an evil demon exerts over somebody or some place (Liddell-Scott-Jones online). ${ }^{1}$ Before Plato, there is no systematic treatment of the concept of daimon, but the word was attested in Homer, as a broad equivalent of theos, god, a divine creature of any kind. Hence, the meaning seems neutral in "with the help of a daimon" (Хомер, 1995, A 792), which, of course, depends on the scope of said help; or pejorative, when Amphimedon accuses an "evil demon" of being the reason for Odysseus' return home (Omero, 2001,

\footnotetext{
${ }^{1}$ On the origin of the term in Plato, Eusebius, and others, see in Riley, 1999, 235.
} 
398c5). Aphrodite is identified as a daimon (Xoмep, 1995, 3.420) - in this sense, the use is almost synonymous with god/goddess. The term in the Iliad is used to denote an occasional manifestation of some indistinct supernatural or divine power (by the grace of the divine power 11.792; going against the will of heaven, 17.98). Daimon might refer to the power which controls destiny, or the (mis) fortune that befalls man (Хомер, 1995, 8.66).

Hesiod tells the story about the people of the Golden Age, who by virtue of Zeus' will were given a special function after their death and were considered pure spirits who live on the earth, are good, deliver from harm, and generally protect the mortals (Esiodo, 2010, 122-123). In the Works and Days, they move invisibly through the land, distributing treasures and taking notes of the right and wrong behaviors of people. Their realm of action is, thus, earth, as opposed to that of the heavenly gods, which spans across the untouchable spheres beyond this world (121-126). They are described as "ten thousand spirits" who watch over all the living people through the entire land (252-253). Due to their lofty, sublime position (from human mortality to divine immortality), Hesiod uses the word daimon, which, like in Homer, is otherwise applied to the deities. In Plato's works, in the Apology, the daimon is a lower deity (27c-e); in Cratylus it is a departed soul (397e-398c); in the Symposium the term refers to the intermediary spirits (202d-203a); in the Republic (620d) and Phaedo (107d), to guardian-spirits. ${ }^{2}$

The ontological system of the Platonist Apuleius is quite complicated and structured in several (at times not too clear) triads, of which one is the triad of gods, demons, and people; the next one is the triad of the First God, invisible gods, and visible gods. Then come the demons: disembodied demons, semi-embodied demons, and embodied demons. The next, quite unclear triad, is the one constituted of God/the Forms, the Form (Forms), and Matter. According to Apuleius, God can be barely somewhat grasped, similarly to the Good from the Republic, which can be understood or intuited. The transcendence of the supreme God according to Apuleius does not present a problem, precisely because the intermediary world of the demons is located between God and the mortal realm.

In his work De Deo Socratis, Apuleius writes that even the human soul should in some sense be called a demon while it resides in the body. He wonders whether the gods kindle desires in our minds, or it is a desire which manifests in each person as their own god (although daimon would be more suitable in this instance). The good desire of the soul is a good god (which is why some people are blessed with a good demon/daimon and a soul perfect in virtue). The soul which retires itself from serving on earth (or being in a body) is also a demon. Apuleius describes a higher and more dignified species of demons, which in number is not smaller than the rest, but is in dignity rather superior, free of the impediments and limitations of the body, and possessing certain powers. Apuleius lists Dream and Love as examples, for they have contrasting powers

\footnotetext{
${ }^{2}$ Thoroughly analyzed in Brenk 1986, 2068-2145, in particular 2085-2087.
} 
(Love has the power to wake up, to stir into action, and Dream has the power to lull into sleep, to calm down, Apuleius, 2017, 15, 150 - 16, 155). This third kind is similar to the first scheme of the demonic realm as an intermediary between the gods and the humans. ${ }^{3}$

If with demon it is referred to some individual creature of purely spiritual, or of incarnate nature, with whom people can meet or have some interaction, then no significant difference between the ancient Egyptian concept of demons and the Greek concept of daimons can be found. However, while there is a clear definition for the category of gods, there is no "axiomatic term that would include all the aspects of demonic idiosyncrasy" (Kousoulis, 2011, XI). Some authors see demons as parts of the category of gods, and distinguish between deities who serve as helpers to the Creator god, spirits, and demons (Meeks, 1971, 18-84; Meeks, 2001, 375-378). In this sense, the Egyptian demons are lower deities, assistants to higher powers, or "incarnated" agents of chaos and evil (Te Velde, 1975, 981; Meeks, op. cit., 375).

\section{Basic conceptual distinctions}

The malice with which demons are associated in Christianity should in no way be attributed, or at least not as a unique or a dominant characteristic, to the demons of Mesopotamia and Egypt. This applies to similar concepts as well. For instance, monstrosity as a concept is not typical for pre-Christian cultures, or at least not as something linked to moral categories. The monstrous varieties of forms are considered manifestations of the evil, the unknown, the foreboding, the uncanny; monsters are often seen as evil incarnate (Lucarelli, 2013, 14; Wengrow, 2011, 131-149), but are not always only, purely, evil. That which is understood as monstrous in ancient Egypt is a product of the composite style of representation specific to the culture, which has its origins in the pictographic hieroglyphic system: the polymorphy of the creatures who look like monsters and are listed as supernatural beings inhabiting the Netherworld is, in fact, a manifestation of their numerous powers; their forms of appearance are sometimes similar or even identical to the ones of the hybrid gods (which are common in Egypt).

In Mesopotamia, the hybrid creatures are mainly demonic, and there is an abundance of monsters, as well as a differentiation between them and the anthropomorphic "civilized" gods. The mixed creatures or "creatures between"

\footnotetext{
${ }^{3}$ The concept of the third class of demons, which does not exist in an incarnate form, is that from the Symposium, of the demonic nature as intermediary between gods and humans. In regards to the inspiration for the human soul, one can turn to Timaeus, where the rational part of the soul is something that God bequeaths as a demon for each individual (90a). The soul which has departed from its earthly existence and has become a demon can be found in Cratylus (a good man who dies has a great honor and becomes a demon, 398b-c).

On the ontological schematics in Apuleius and the typology of demons, seе Тодоровска, 2018, 176-185; 2020, 94-101.
} 
(useful German compound words being Misch/en/wesen and Zwischenwesen) are entities of a mixed nature, who have a hybrid physical form or are spiritually intermediary creatures between the higher and the lower ontological sphere. The demon udug (utukku) may be evil (hul, lemnutu), but it can be ambivalent and even good; lama are benevolent creatures who may also be evil and harmful. A famous case is the demon Pazuzu, who, although malevolent and harmful (bringing winds and storms, famine during draughts, infestations of vermin, and other troubles), helps with the protection against other evil influences, plagues, and misfortunes.

Smith determines a "locative" category of monsters, inspired by the taxonomy in Douglas and other authors. Monsters (and numerous demons) live in places outside of the ordered world, like deserts, oceans, the outskirts of the ordered sphere, the underworld (Smith, 1978, 429). This makes for an interesting remark from the aspect of phenomenology of place: if monsters are not to be distinguished from demons just by their appearance (like hybrids with multitudes of composite animal bodies in the monsters group, versus hybrids with human characteristics or attributes in the demons group), then it can be claimed that monsters belong to places more than demons do. Demons "escape place", representing the chaotic, the distant, the undefined, the rebellious (ibid). They are wanderers (it is not by chance that one of the most prominent demonic groups in Egypt is called "the Wanderers"). Besides these, however, there are demons who are bound to certain places, like the ones from the Netherworld, or the guardians of the sacred places.

The corporeality of demons is one of the problems of their ontological determination. In the Egyptian funerary compositions, demons have bodies, frequently of a hybrid nature, which is also typical for the demons in Mesopotamia (Black and Green, 1992, 64-65). The Christian conceptions of demons are not exactly of "incarnate" evil, for they are not exactly corporeal, but rather spiritual beings. The physical manifestation of demons can be seen as a symbol of man's conflict with oneself and with moral principles, a symbol of some cognitive dissonance. The physical manifestations of demons in the Christian iconography incline towards the monstrous experienced as abject.

In Homer and some of the early Greek folkloric conceptions, some similarities to the ancient Egyptian beliefs in demons as independent creatures belonging to the external world can be found. In this sense, it is possible that Plato has re-elaborated an already existing folkloric belief, which was present in Homer, according to which demons were not part of the internal I of man, but contrary, a personification of the external supernatural powers that provoke defilement or madness (this plays a central role in Aeschylus, 1991, 1006 for example; see Wilford, 1965, 217-232).

The daimon (commonly mentioned individually, not as a member of a collective) can act like the gods, but it differs from them in that it remains undefined and anonymous. This concept is later developed in the Platonic idea of the 
soul which belongs to the individual, in contrast to the anthropomorphic gods. ${ }^{4}$ Greek daimonology differs from the demonology of the Near Eastern beliefs, which applies to the category of demons who manifest themselves as hybrids, animals, or anthropomorphic creatures, and who are oftentimes at the center of apotropaic rituals to decrease or transform their influences over the lives (and death) of people.

There is the assumption, however, that the demonology of the Near East influenced the Greek thought in its representation of potentially evil spirits in animal, or dominantly hybrid form, with bodily components of birds or snakes, for example (the appearance of the Assyrian griffon-demon frequently shown in pair with the sphynx, around the fourteenth century B.C. in Greece, merits a mention here, Black and Green, 1992, 99-101). Burkert analyzes the Near Eastern influences on Greek demonology, mainly focusing on the treatment of diseases of demonic origin, and through a comparison of motifs and concepts, such as Lamaštu and Lamia (Burkert, 1992, pass.). The terrifying figure of Gello used to intimidate unruly children, is mentioned in the works of Sapho - Gello was said to abduct and eat young children. An even scarier character is Lamia, already mentioned in the archaic period and preserved all through to the modern folklore (see West, 1991, 361-368). Lamia is grotesque, repulsive, and disgusting beyond measure, and her main characteristic is that she steals children, sometimes even from inside their mothers' wombs. In this sense, she greatly resembles the demon Lamaštu. There is a similarity in the names, too, which was obscured by the early reading of the name of Lamaštu as Labartu (Burkert, 1992, 83).

Around the Mediterranean Sea, fantastic beasts, like the griffon and the sphynx, belong to the iconography of the demonic, and the demonic is, as previously mentioned, often linked to the monstrous. Nevertheless, one should keep in mind that the things which appear to be grotesque for us, as combinations of elements from different creatures, extra heads or extremities, etc., placed in their proper context, are actually amalgamations of religious symbols, and not a description of some great evil through monstrosity and ugliness (or abjectness). ${ }^{5}$ Within the magical and ritual contexts of the cult played out in the temples, polymorphic images of gods and demons in the Greco-Roman period

${ }^{4}$ On a folklore level there is very little material, remarks Brenk $(1986,2040)$. What we have extant from the early imperial period is a combination of philosophical literature, with frequent references to Plato, and with mere traces of folk beliefs. Therefore, it is difficult to say how accurately these beliefs can be reconstructed. As it was mentioned, daimons were equated with spirits of nature, and in the philosophical tradition they were treated as the soul or the reason of the human being. Still, it is possible to deduce that philosophical authors treated demonology with a certain hesitance, and as an area open for both belief and suspicion. It is, therefore, more suitable to speak of daimonology in the authors of philosophy, as an area that has its roots in the folkloric and Homeric tradition, see in Brenk (op. cit., 2041).

5 See the suggestions in Bazin, 1992, 25-43. Bazin recognizes a "demonic style" in art (images of the mythical representations of the arch-enemy, which display ugliness, 
are plentiful (Fischer, 1987, 12-26 apud Lucarelli, 2011, 114, ft. 16/non vidi; Hornung, 2000, 19). Some of the demons were believed to be created by the gods for certain personal goals, and others were human beings (alive, or more likely dead). Demons were believed to perform auxiliary functions: they helped the deities in their communication with humans so that the deities could be free from such matters (Meeks, 2001, 375). In this sense, demons are ontologically between the deities and the humans. Generally speaking, there is no cult dedicated to the demons - not until the New Kingdom, and if Seth is exempt, seen as he is a god, not a demon (Te Velde, 1975, 981; Assmann, 2001, 7-8). Although "demonic nature" or "demonic influences" are used, one must be aware that the powers of demons were (believed to be) not universal, but rather that their kinds and domains depended on the characteristics, the roles, and the ranks of particular demons. ${ }^{6}$

\section{Harmful demons}

The fear of demons was widespread through ancient Egypt, and dealing with demons meant combining spiritual and medical methods. Spells, messages, and prayers were accompanied by instances of medical practice. There were incantations and strict rituals to combat the evil aggressors.

It was believed that the anonymous hordes of demons; the groups, or gangs or enemies and adversaries to the gods; the unjustified dead and the damned; all the inimical transformed spirits; the separate groups of demons of darkness, the disease-bringers, the messengers and the slaughterers, ${ }^{7}$ who inhabited the Netherworld together with the gods, were capable of crossing the borders between worlds, and attack like bandits, cause physical and mental illnesses, emotional disorders and other troubles, possessing the living spaces, the bodies and the souls of humans. Numerous incantations are associated with the protection against such nefarious creatures. The division of demons in ancient Egypt, on the basis of different spells, magical prescriptions, and apotropaic means ${ }^{8}$ can be made according to the distinct conditions or illnesses they produce, as well as the appropriate techniques against them.

plurality, excess, chaos), once popular among the Eastern civilizations, and contrasts it with the Greek arts, free from such diabolical influences, (op. cit., 29).

${ }^{6}$ On the tasks demons would perform, and their gatherings in gangs, see Meeks, 1971, 44-45; Wilkinson, 2003, 81.

${ }^{7}$ In the magical texts the names of these three main demonic gangs are used interchangeably, probably due to the fact that they all have the same basic function: to inflict punishment, by bringing plagues, diseases, famine and troubles (Lucarelli, 2017, 58).

${ }^{8}$ The creatures contained in the encyclopedic texts, very thoroughly compiled by the Ancient Egyptians, are those who were believed to inhabit the cosmos. The creatures of chaos, like demons, do not feature in these kinds of enumerations. For example, see the hierarchical list of categories of superhuman beings from the Onomasticon of Amenemipet (Gardiner, 1947, 37). 
Apart from the harmful demons who cause difficulties and bring sickness, there are useful, benevolent demons, whose role is to protect humans and places. Demons are usually grouped by seven, or in pairs or triplets, but solitary agency is prevalent as well, like of one dedicated (demonic) person. If the division is made based on the world in which they live, there are two categories. There are demons who live in the Netherworld, fixed, tied to a certain place that serves as their abode (Lucarelli, 2013,17). The other category is that of traveling demons, who pass between the earth and the world beyond, acting through the environment of humans by the orders from the gods. These are the wandering demons, who move from one place to another, who are to blame for the proliferation of contagious diseases, for the accidents and troubles of people, as well as for the many instances of demonic possession. These categories are distinct, but it can be surmised that in some way they complement each other in the religious belief in evil incarnate (Lucarelli, 2006, 204). Wandering demons are scarcely represented, but they do get some mentions in the collective names of the amuletic and magical texts. The primary sources for the knowledge about demons who cause difficulties and harm to humans are the incantations and the spells preserved on papyri and ostraca. The magic usually consists of a recitation, a series of rituals with strictly determined components that must be made and used. A substantial number of spells are designed as a medical intervention, in order to help with physical and mental health issues, or as formulae for the protection of individuals or places from earthly or supernatural impostors.

The main role of the "slaughterers", as implied by the name, is to bring diseases, plagues, pain, and suffering. ${ }^{9}$ In this sense, they were also seen as deputies to the goddess of disease and fear, Sekhmet (in her harmful aspect, Schipper, 2007, 7). Most of the magical texts from the New Kingdom mention magical practices performed in order to heal the patients from the physical and psychical disorders caused by the slaughterers (Borghouts, 1978, 14-15).

The messengers have a similar evil influence. They were believed to be sent to execute orders from the gods, which means that they had both good and bad roles, depending on the subjects of their interventions (for or against whom and with which objective). They are connected to different deities, but in

\footnotetext{
${ }^{9}$ Due to the often-recurring demonization of disease, numerous magical practices and various incantations were used along with the medical prescriptions. Therefore, the ancient Egyptian approach to healing and public health (in an early stage) is magicomedical. From the many testimonies of the Magico-medical papyri, quite popular during the Ramses period (although originating in the Middle Kingdom), the application of this synergy is clear. From the extant sources it is apparent that magic and rituals to banish demonic diseases from the body (or the exorcism of demons) were considered to be powerful tools, complementary to the medical science.

From the extant sources it seems that diseases which do not present themselves with visible physical symptoms, like headaches or epilepsy, were more commonly linked to the demonic, than other types of conditions, like poisonous insect bites. Dermatovenereological diseases, for example, were often considered as manifestations of demonic influences (Leitz, 1999, 55-57, 80-81; Lucarelli, 2017, 55).
} 
funerary, magical, and temple texts they are the messengers of Sekhmet, or of Seth, which makes them dominantly destructive (Te Velde, 1975, 983; Lucarelli, 2017b, 136). An irreplaceable function of these divine messengers is the punishment of the sinners in the Netherworld, in the last judgment (for example: ... If this book is used on earth, he, i.e. the deceased, shall not be seized by the messengers who attack those who commit wrong in the whole earth, Book of the Dead/BD \#163, Lepsius, 1842, pl. 77.17-18, apud Lucarelli, 2005, 205). Demons were believed to be unable to see or to have an evil eye. The disability does not end here - they were believed to be deaf or speech-impaired, meaning that they spoke unintelligibly, that they howled or shrieked. The gender of demons is not essential, though dominant are the mentions of male demons (Te Velde, 1975, 981).

Ancient Egyptian medico-magical professionals (doctors, mages, healers, priests) were aware of the need for the patient to be rid of the disease-bringing demon, to be saved from the power that comes from the world beyond, from partially-divine (or divine-adjacent), dangerous creatures. Therefore, treating the epiphenomena of the disease, as well as its causes, was believed to be more effective if accompanied by magic amulets, or magical supplications. An interesting issue arises as to the interpretation of the texts where demons who bring diseases are mentioned - perhaps it is a personification of the disease, or a technical usage of demonic names in the medical jargon in order to express the idea of the disease. If this is the case, then it is about understanding disease as an external aggressor or an impostor in the body (developed in Pinch, 1994, 133-146). It is particularly interesting to imagine how ancient Egyptian physicians and medico-magical workers would understand auto-immune diseases, and whether it would be a belief in an internal aggressor (the patient's own body) understood as demonic self-destruction.

\section{Useful demons}

As it was previously mentioned, the messengers are associated with the Netherworld. They serve to execute divine orders, and in the realm of the dead, they collaborate with Osiris, sort of like his demon army. ${ }^{10}$ The existence of the messengers both as disease (and trouble) bringing demons, and as helpers in the Netherworld, goes along the idea of the blurred boundaries between the worlds in ancient Egypt, and with it, of the funerary and the ordinary quotidian magic. These demons are mentioned in the funerary texts and the magical texts from the New Kingdom and later, which deal with the regular matters of daily life (of the living). Lucarelli remarks that if it stands true that two realities should be distinguished in ancient Egypt - the world of the living and the world of the dead - these realities still seem complementary in the religious belief in

\footnotetext{
${ }^{10}$ The aforementioned formulation from the BD \#163 states that if the book is used on earth, the person who is using it will not be abducted by the messengers, who act like enemies to those culpable of wrongdoings.
} 
evil spirits. The demons of the daily religion and those featured in the amuletic and the magical texts are sometimes the same ones who appear in the funerary texts. The idea of the need for divine intervention and protection in the repelling or the attenuation of these demonic forces remains the same both in the world of the living and the world of the dead (Lucarelli, 2017, 57).

The wandering demons who bring disease appear also in non-medical contexts, in the ritual texts of the temples, and in incantations of funerary magic. On the one hand, this means that the demonization of diseases is closely linked to the divine and the ritual religious sphere, on the other hand, that demons are not only malevolent or harmful. Failing to perform the ritual duties to appease the potentially angry gods, and desacralizing the secret (liminal) passages might cause retaliatory demonic actions.

The ambivalent nature of demons is interesting: demons were considered creatures who can move on the edge, or the boundaries, between the realms of the divine and the human, who can pass between the world of the dead and the living, who are on the verges of the cosmos and the chaos, filling either with the principles of Ma'at (order, harmony, justice, truth, etc.), or Isfet (disorder, violence, injustice, untruth). Therefore, demons are able to punish for bad behaviors, behave badly themselves, save and protect, and preserve the good, and also to cause troubles, diseases, nightmares, feuds, and other problems.

The benevolent demons of ancient Egypt are the guardians of some areas in the Netherworld and of the sacred places, who become evil and harmful towards those who do not know the appropriate magic words, or the secret names of demons, necessary for suitable encounters with them and for proper salutations, in order to secure a safe passage. These guardians are a part of the numerous inhabitants of the underworld life after death, where the Sun god who descents in his journey to the Netherworld must merge with the deceased body of Osiris. These might even be tentatively considered "apotropaic gods" (Altenmueller, 1977, 635-640).

The guardians and protectors of liminal zones, entrances, thresholds, passages, and especially, of Osiris during the process of his dying and rebirth, are a very important segment of the apotropaic practice. These guardians, benevolent demons, during the Pharaonic period served as observers and as gatekeepers to the Netherworld, as sentinels of the sacred places on earth. The characteristics and functions of these demons were a continuation of the beliefs in their nature as featured in the mythology about the world beyond, preserved from previous narrative frameworks. An assumption can be made that the connection between temples, tombs, and guardian demons is the result of the development of the concept of mortal god (or the gods' mortality), according to which the gods, just like the mortals, grow old and die. However, the presence of guardian demons and the quite prevalent practice of having supernatural creatures guard the sacred places should not be connected with or explained by, the concept of mortal gods. A simpler and more probable explanation would be that the guardian demons of temples, of the sacred spaces, and of the Nether- 
world, are particularly important due to the intense need to keep the temple-the world (i.e., the cosmos) safe from the chaos of the threatening unknown. ${ }^{11}$

The guardians are topographically limited: they have a benevolent function towards those who possess the secret knowledge of the demons' names and of the ways to confront them in the Netherworld, and the role of protectors of certain sacred places, where their powers are most pronounced. These are the guardian-demons or the wrt-demons from the Oracular amuletic decrees. These dominantly fixed demons are connected to the sacred places they inhabit, like rivers or mountains, and their harmful influence is contained over the unauthorized passers-by (trespassers), whom they attack (Leitz, 2002, 506). This aggressive nature of the guardian demons is not evil per se - they are fiercely protective of the places for which they are responsible. This is the reason they essentially differ from the wandering demons who disseminate disease, who possess human bodies, or infest the places to which they do not belong. The guardian demons are crucial for the protection of the world beyond, for they watch over the gates and passages of the world of the dead, as well as the liminal areas to which they are appointed.

The creatures who mind the gates, portals, and doors are described in $\mathrm{BD}, 144-147$; the gates and the guardians of the gates to the Netherworld are the topics of other funerary texts as well, such as the Book of the Gates and the Book of the Night. The demonic guardians of the sacred liminal places, between the earth and the Netherworld, between the living and the dead, the sacred and the profane, the pure and the impure, are featured in the beliefs in Mesopotamia, and in Buddhism and Hinduism, for example. In the magic spells from the $B D$, the deceased communicate with the guardians of the gates, often in unmediated dialogue. ${ }^{12}$

On an ontological level, they are demons, not deities (and definitely not people). In the case of the guardians of the gates, their powers and functions are focused on the liminal sacred place (passage) they are guarding. In the pictographic representations, they are hybrid creatures (a human body with an animal head), or completely anthropomorphic. The fact that these demons are represented visually, as opposed to other demons who only get occasionally mentioned, confirms the need for the deceased to not only know them by their names, which is necessary (the knowledge of the name is one of the main principles of funerary magic) ${ }^{13}$ but also to have their clear visual portrayals so that he/she can recognize them upon encounter (Lucarelli, 2010, 87; Guilhou, 1999).

${ }_{11}$ This explanation matches the contents of the magical formulae 144-147 from BD, in which the demonic inhabitants of the underworld, the gatekeepers, are featured. The guardians of the important elements of the Netherworld are keepers of the sacred places in the sacred space (on earth).

12 These spells appear on coffins, in tombs and in temples (Kákosy, 1982), and the forerunners of 144 and 147 are attested in the Coffin texts (Barguet, 1967, 190, 203; Lucarelli, 2010, 86).

${ }^{13}$ On the necessity to know the names, and on knowing bas of the sacred places, see Lucarelli, 2006, 95-104. 
This text is not concerning the iconography of such variants, although such analysis might help to identify a prototype from which different papyri stem, or, if it is an art history analysis of the origins, to identify the workshop which initially produced them, as well as the subsequent transformations. From a theological perspective, it is possible that the inconsistency in the representation (each guardian has a different shape of the head, for example) symbolizes their ability to manifest themselves in different forms. The guardians, who initially belonged to the world beyond, in the ritual context of the Ptolemaic practice help reinforce the army of temple sentinels and protectors. ${ }^{14}$

The function of guardian demons is to open the gates to the Netherworld for Osiris, which means that they represent a key cosmological-ritual dimension of keeping the order of the world, through the rebirth of Osiris and his ruling over the world of the dead. In the version of the Dendera temple, there is a scene showing Horus, accompanied by Anubis, who salutes Osiris at the entrance of the gates (in the papyri a role played, expectedly, by the deceased, who was central in this context). In the $B D$, parts of 145 and 146, from papyrus from the Twenty-first Dynasty, the deceased is displayed offering his heart to the guardians (see in Gozdawa-Golebiowska, 2009).

The guardian demons are a part of the guardian spirits of temples because their function is to open up the way, the passage, of the doors and gates separating the different realms (the sacred and the profane, the earthly and the underworldly). Both funerary magic (the opening of the gates to the Netherworld) and temple rituals (the access to the most secluded areas where the most secret rituals are played out) depend on this ability. This is why guardian demons are an essential part of, or the connection between, the quotidian, ordinary ritual magic, and the solemn funerary magic. ${ }^{15}$

\footnotetext{
${ }^{14}$ This function of underworld guardians is perhaps inspired by the existence of human, mortal guardians of the temple gates, which was a responsible and sacred occupation (see Leprohon, 1994).

It is possible that it is the case, of course, but in primordial and later beliefs the direction of importance of any action goes from the sacred to the profane - the sacred is primary, and thanks to it, and according to it, the profane is formed. A more likely assumption would be that it is a matter of combined practical and religious functions: temples do need guarding, but it is done according to the order of the Netherworld and the portals leading to it.

${ }^{15}$ A recurring statement by the deceased $(B D, 145)$ is "... open a passageway for me, because I know you, I know your name, I know the name of the god who guards you"; cf "... the doors to the Netherworld are open for you (Osiris)" (144). In a ritual of the mysteries of Osiris, in which Osiris must be allowed to rule in the name of the Silent Land (the Netherworld), different demonic and divine inhabitants of the underworld are mentioned, and asked to grant access to the god (that is, to the deceased), and to protect and worship him. In the ritual it is essential to know the names of the demons, in order to receive a permission to cross (from P. MMA 35.9.21, apud Goyon 1999, 17-26).

A thorough comparison of the names of the guardians from the BD, 144 (P. Turin 1791: Lepsius 1842, pls. LX-LXI; from the temple in Dendera, Dendara X, 345-346; Cauville,
} 
This text is a preliminary attempt at bringing closer to the Macedonian public the belief in demons as part of the broad and multifaceted concept of evil incarnate. The numerous and multilayered conceptions about demons in ancient Egypt serve as an appropriate introduction to the old beliefs in the demonic, the supernatural, the monstrous. Although demons are generally associated with or included in, the category of pure (incarnate) evil, there is some ambivalence to the concept in pre-Christian beliefs. Demons (and monsters, or hybrids) are not only evil and harmful.

Thus, in this text, the ancient Greek conception of daimons is shown, in an attempt to compare it with the ancient Egyptian beliefs. The demons of ancient Egypt are examined in their dual functions: of disease carriers, bringers of misfortunes and troubles, and as guardians of some designated, sacred places. The ambivalence of the demonic is notable also in the fact that even the frightening and horrible messenger-demons, culpable for the misery in the world of the living, are actually enforcing divine orders, and helping to appropriately deliver the punishments in the world of the dead. The guardian demons have key sacred ontological roles in the preservation of the boundaries between the realms of the world. Therefore, it can be concluded that while demons should not be separated from the concept of evil (incarnate), they should also be treated as an ambivalent, and not just an evil and harmful non-human (or superhuman) existence in the world.

1997, 1:186-87; and in the ritual papyrus of Imhotep, p. Goyon, 1999, 34-5, cols. 7/16-8/5, pls. VI-VIIA, in Lucarelli, 2010, 93, table 1). 


\section{REFERENCES}

Aeschylus, Helen H. Bacon (1991). Seven Against Thebes (Greek Tragedy in New Translations). Oxford: Oxford University Press.

Altenmueller, H. (1977). Gotter, apotropaeische. In W. Helk, W. Westendorf, eds., Lexikon der Aegyptologie, II, Wiesbaden: O. Harrassowitz, pp. 635640.

Apuleius (2017). Apologia. Florida. De Deo Socratis, C. P. Jones, trans. \& ed. Loeb Classical Library 534, Cambridge: Harvard University Press.

Assmann, J. (2001). The Search for the God in Ancient Egypt, Ithaca and London: Cornell University Press.

Barguet, P. (1967) Le livre des morts des anciens égyptiens. Littératures anciennes du Proche Orient 1. Paris: Les Editions du Cerf.

Bazin, G. (1992). The Devil in Art. In B. P. Levack, ed., Witchcraft and Demonology in Art and Literature, Vol. 12, London: Routledge, pp. 25-43.

Black, J. and Green, A. (1992). Gods, Demons and Symbols of Ancient Mesopotamia. An Illustrated Dictionary. London: British Museum Press.

Borghouts, J. (1978). Ancient Egyptian Magical Texts. Nisaba 9, Leiden: Brill.

Brenk, F. (1986). In the Light of the Moon: Demonology in the Early Imperial Period. ANRW, II, 16. 3, pp. 2068-2145.

Burkert, W. (1992). The Orientalizing Revolution. Cambridge: Cambridge University Press.

Esiodo (2010). Opere e giorni, A. Ercolani (a cura di). Roma: Carocci.

Gardiner, A. H. (1947). Ancient Egyptian Onomastica. London: Oxford University Press.

Goyon, J.-C. (1999). Le papyrus d'Imouthès Fils de Psintaês. New York: MMA.

Gozdawa-Golebiowska, K. (2009). Chapter 146 of the Book of the Dead of wsrHAtms SR 6/10249 TR 14.7.35.7. Cairo: Egyptian Museum Collection), GM 223, pp. 53-56.

Guilhou, N. (1999). Génies funéraires, croque-mitaines ou anges gardiens? Étude sur les fouets, balais, palmes et épis en guise de couteaux. In S. Aufrère, ed., Encyclopédie religieuse de l'univers vegetal, vol. 1, pp. 365-417. Montpellier: Université Paul-Valéry.

Хомер (1995). Илијада, М. Д. Петрушевски, прев. Скопје: Детска радост.

Hornung, Е. (2000). Komposite Gottheiten in der ägyptischen Ikonographie. In Images as media. Sources for the cultural history of the Near East and the Eastern Mediterranean (1st millennium BCE), Orbis Biblicus et Orientalis (OBO) 175, pp. 1-20.

Kákosy, L. (1982). Temples and funerary beliefs in the Graeco-Roman epoch. In L'égyptologie en 1979: Axes prioritaires de recherches. Paris: Editions du Centre national de la recherche scientifique, pp. 117-127.

Kousoulis, P. (2011). Introduction: The Demonic Lore of Ancient Egypt: Questions on Definition. In: P. Kousoulis, ed., Ancient Egyptian Demonology: Studies on the Boundaries between the Demonic and the Divine in Egyptian Magic. 
Leuven - Paris - Walpole: Uitgeverij Peeters en Departement Oosterse Studies, pp. I-XXI.

Leitz, C. (1999). Magical and Medical Papyri of the New Kingdom, (Hieratic Papyri in the British Museum) 7. London: British Museum Press.

Leitz, C. (2002). Lexikon der ägyptischen Götter und Götterbezeichnungen, Vol. 2. Dudley, MA, and Leuven: Peeters.

Leprohon, R. J. (1994). Gatekeepers of this and the other world. JSSEA 24, pp. 77-91.

Lucarelli, R. (2017a). Illness as Divine Punishment. The nature and function of the disease-carrier demons in the ancient Egyptian magical texts. In $\mathrm{S}$. Bhayro and C. Rider, eds., Demons and Illness from Antiquity to the EarlyModern Period. Leiden-Boston: Brill.

Lucarelli, R. (2017b). The Significance of the Book of the Dead Vignettes. In F. Scalf, ed., Book Of The Dead, Becoming God in Ancient Egypt, Chicago: Oriental Institute Museum Publications.

Lucarelli, R. (2006). Demons in the Book of the Dead. In B. Backes, I. Munro, S. Stöhr, eds., Totenbuch-Forschungen: Gesammelte Beiträge des 2. Internationalen Totenbuch-Symposiums, Bonn, 25. bis 29. September 2005, Leiden: Brill, pp. 203-212.

Lucarelli, R. (2010). The guardian-demons of the Book of the Dead. British Museum Studies in Ancient Egypt and Sudan 15, pp. 85-102.

Lucarelli, R. (2013). Towards a Comparative Approach to Demonology in Antiquity: The Case of Ancient Egypt and Mesopotamia. Archiv für Religionsgeschichte, Band 14, Heft 1, pp. 11-25.

Lucarelli, R. (2013). Towards a Comparative Approach to Demonology in Antiquity: The Case of Ancient Egypt and Mesopotamia. Archiv für Religionsgeschichte 14, 17, pp. 11-25.

Meeks, D. (1971). Génies, anges et démons : Egypt - Babylone - Israël - Islam - Peuples altaïques - Inde - Birmanie - Asie du Sud-Est - Tibet - Chine. Paris: Éditions du Seuil.

Meeks, D. (2001), Demon. In D. Redford, ed., Oxford Encyclopedia of Ancient Egypt, vol. I. Oxford: Oxford University Press, pp. 375-378.

Omero (2001). Odissea, F. Ferrari (a cura di). Torino: Unionie TipograficoEditrice Torinese.

Pinch, G. (1994). Ancient Egyptian Magic. London: BMP.

Plato (1997). Complete Works. M. J. Cooper, trans. \& ed. Indianapolis: Hackett Publishing Company.

Riley, G. J. (1999). Demon. In: K. van der Toorn, B. Becking, P. W. van der Horst, eds., Dictionary of Deities and Demons in the Bible. Brill: Leiden-BostonKöln, p. 235-240.

Schipper, B. (2007). Angels or Demons? Divine Messengers in Ancient Egypt. In F. Reiterer, T. Nicklas, K. Schopflin, eds., Angels: The Concept of Celestial Beings: Origins, Development and Reception. New York: Walter de Gruyter. 
Smith, J. Z. (1978). Towards Interpreting Demonic Powers in Hellenistic and Roman Antiquity. ANRW, 2. 16. 1, pp. 425-439.

Te Velde, H. (1975). Dämonen. In: W. Helck, W. Westendorf, eds., Lexikon der Ägyptologie, vol. I. Wiesbaden: O. Harrassowitz, pp. 980-984.

Тодоровска, М. (2018). Одредени аспекти од онтолошките системи на Апулеј и на Нумениј. Филозофска трибина, 41, 22-23, стр. 175-195.

Тодоровска, М. (2020). Неискажливата природа на божественото. Скопје: Филозофски факултет.

The Online Liddell-Scott-Jones Greek-English Lexicon. Available at http://stephanus. tlg.uci.edu/lsj/\#eid=1 [accessed 01 May 2021].

Wengrow, D. (2011). Cognition, Materiality and Monsters: The Cultural Transmission of Counterintuitive Forms in Bronze Age Societies. Journal of Material Culture, 16:2, pp. 131-149.

West, D. R. (1991). Gello and Lamia, Two Hellenic Daemons of Semitic Origin. Ugarit-Forschungen, 23, pp. 361-368.

Wilford, F.A. (1965). Daimon in Homer. Numen 12:3, pp. 217-232.

Wilkinson, R. H. (2003). Demons. In The Complete Gods and Goddesses of Ancient Egypt. London: Thames and Hudson: p. 81. 